ORIGINAL ARTICLE

\title{
Identification of a locus for type I punctate palmoplantar keratoderma on chromosome 15q22-q24
}

\author{
A Martinez-Mir, A Zlotogorski, D Londono, D Gordon, A Grunn, E Uribe, L Horev, I M Ruiz, \\ N O Davalos, O Alayan, J Liv, T C Gilliam, J C Salas-Alanis, A M Christiano
}

J Med Genet 2003;40:872-878

See end of article for authors' affiliations

Correspondence to:

Dr A M Christiano, Departments of Dermatology and Genetics \& Development, Columbia University, College of Physicians \& Surgeons, 630 West 168th Street VC1526 , New York, NY 10032,USA; amc65@ columbia.edu
Background: The identification of the molecular basis of disorders of keratinisation has significantly advanced our understanding of skin biology, revealing new information on key structures in the skin, such as the intermediate filaments, desmosomes, and gap junctions. Among these disorders, there is an extraordinarily heterogeneous group known as palmoplantar keratodermas (PPK), for which only a few molecular defects have been described. A particular form of PPK, known as punctate PPK, has been described in a few large autosomal dominant pedigrees, but its genetic basis has yet to be identified. Aim: Identification of the gene for punctate PPK. Methods: Clinical examination and linkage analysis in three families with punctate PPK.

Results: A genomewide scan was performed on an extended autosomal dominant pedigree, and linkage to chromosome 15q22-q24 was identified. With the addition of two new families with the same phenotype, we confirmed the mapping of the locus for punctate PPK to a $9.98 \mathrm{cM}$ interval, flanked by markers D15S534 and D15S818 (maximum two point lod score of 4.93 at $\theta=0$ for marker D15S988). Conclusions: We report the clinical and genetic findings in three pedigrees with the punctate form of PPK. We have mapped a genetic locus for this phenotype to chromosome $15 q 22-q 24$, which indicates the identification of a new gene involved in skin integrity.
$\mathrm{P}$ almoplantar keratodermas (PPKs) are a family of diseases characterised by hyperkeratosis of the palms and soles. Defects in different components of the desmosomes and the keratin filaments have been described, but many forms of the disease still have an unknown molecular basis. PPK is clinically and genetically heterogeneous, and can be classified into three main categories according to the affected area of the palms and soles: diffuse, focal, and punctate. ${ }^{1}$ It can be inherited as an autosomal recessive, autosomal dominant, mitochondrial, or possibly, $\mathrm{X}$ linked recessive trait. The autosomal dominant forms of PPK represent one of the most common defects of keratinisation; ${ }^{2}$ however, their molecular basis remains largely unknown. The clinical picture of PPKs can range from strict involvement of the palms and soles, accompanied by epidermolysis (epidermolytic and non-epidermolytic forms), to a wider ectodermal defect (palmoplantar ectodermal dysplasias), or associated with cardiomyopathy, ${ }^{3-5}$ deafness, ${ }^{67}$ or different forms of cancer. ${ }^{1}$ Examples of the latter are tylosis (focal nonepidermolytic PPK) with oesophageal cancer, ${ }^{8}$ Huriez syndrome (diffuse PPK associated with squamous cell carcinoma), ${ }^{9}$ and punctate PPK, occasionally associated with various types of malignancies. ${ }^{210}$ Association of epidermolytic diffuse PPK with breast and ovarian cancer has also been described in a large pedigree. ${ }^{11}$ Mutational analysis, however, determined that the PPK phenotype was caused by a mutation in the KRT9 gene, while the cancer phenotype was the result of a mutation in the BRCAl gene. ${ }^{12}{ }^{13}$

As is the case for many other human inherited skin diseases, PPKs exhibit extensive genetic heterogeneity. So far, mutations in more than fifteen genes have been identified in different forms of PPK. ${ }^{14}{ }^{15}$ These genes code for components of the intermediate filaments, such as keratin $1,{ }^{16}$ keratin $6 \mathrm{a},{ }^{17}$ keratin $6 \mathrm{~b},{ }^{18}$ keratin $9,{ }^{19}{ }^{20}$ keratin $16,{ }^{21}$ and keratin $177^{21} 22$ the desmosome, such as desmoglein $1,{ }^{16}{ }^{23}$ desmoplakin, ${ }^{424}$ and plakoglobin; ${ }^{326}$ gap junction channels, such as connexin $26,{ }^{27}$ connexin $30,{ }^{28}{ }^{29}$ and connexin $31 ;{ }^{30}$ loricrin, a major component of the cornified cell envelope; ${ }^{31}$ and a diverse group comprising the proteolytic protein cathepsin $\mathrm{C}^{32}$ SLURP-1, ${ }^{33}$ and a mitochondrial transfer RNA for serine, MTTS1. ${ }^{6}$

The molecular basis of a particular form of PPK, punctate PPK (OMIM \#148600), is still unknown. Punctate PPK can be inherited as an autosomal dominant trait or it can present as an acquired disease. Both the inherited and acquired forms have been associated with malignancies, such as Hodgkin's disease, renal, breast, pancreatic, and colonic adenocarcinomas. $^{210}$ The main clinical features include the presence of multiple small keratotic lesions on the palms and soles, with variable nail involvement. ${ }^{34}{ }^{35}$ It is typical for these punctate lesions to coalesce on the soles, which are subject to continuous high pressure. The inherited form of punctate PPK shows age dependent penetrance, with an estimated age of onset between 10 and 33 years, ${ }^{1}{ }^{1035}$ and its molecular basis remains unknown. In a previous study, the keratin gene clusters on chromosomes 12 and 17 were excluded as the disease causing genes. ${ }^{36}$

In the present study, we report the clinical and genetic findings in three pedigrees with the punctate form of PPK and the identification of the first locus for this phenotype, on chromosome 15. The fact that there are no candidate known genes in this chromosomal location suggests the presence of a new gene with an important role in skin integrity.

\section{SUBJECTS AND METHODS}

We studied three different pedigrees with punctate PPK (fig 1). The first two families were a Jewish family originating from Syria (PPKl) and an Arab-Israeli family Abbreviations: ITGA1 1, integrin alpha 11 gene; LOXL1, lysyl oxidase-
like 1 gene; OMIM, Online Mendelian Inheritance in Man; PPK, palmoplantar keratoderma 

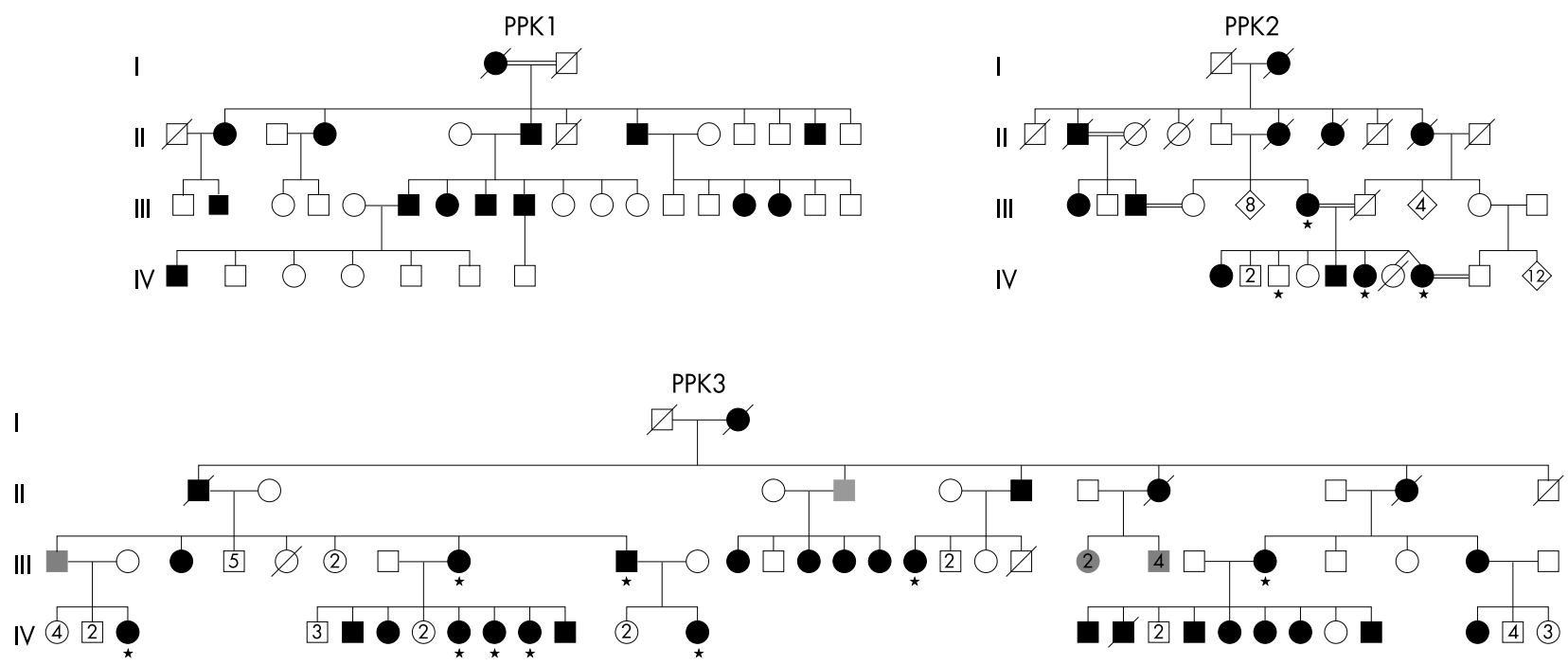

Figure 1 Pedigrees of families with punctate PPK. Affected and unaffected individuals, and those of unknown phenotype are denoted by black, white, and grey symbols, respectively. Most of the living individuals from family PPK1 were available for this study. Available DNA samples from families PPK2 and PPK3 are indicated by an asterisk (*).

(PPK2). They comprised 14 and 12 reported affected family members over four generations (fig 1). Thirteen and three affected individuals from pedigrees PPK1 and PPK2 respectively and a number of unaffected individuals were available for this study, and therese were interviewed and examined by two physicians (A Z and L H). The third family, PPK3, originated from Mexico, with 31 reported affected individuals over four generations (fig 1). For this study, we had access to samples from nine affected family members. The clinical features of this pedigree have been reported previously. ${ }^{37}$

\section{Genomewide scan}

Blood samples from affected and unaffected family members were collected following informed consent, and genomic DNA was extracted using the PureGene DNA Isolation Kit (Gentra Systems, Minneapolis, MN, USA). A genomewide scan was performed on pedigree PPKl. Twelve affected and 16 initially unaffected individuals were included in the study. The strategy for the genomewide scan has been described elsewhere. ${ }^{38-40}$ Briefly, a panel of 324 microsatellite markers was used, with an average marker spacing of $10 \mathrm{cM}$ and a semi-automated fluorescence based genotyping system. Most of the markers were chosen from version 8.0 of the Marshfield fluorescence labelled genome screening set.

Microsatellite markers used for the fine mapping of the $P P K$ locus on chromosome 15 were chosen from the Marshfield genetic map, ${ }^{41}$ and PCR primer sequences were obtained from The Genome Database and the Cooperative Human Linkage Center. PCR products were resolved on $6 \%$ non-denaturing polyacrylamide gel electrophoresis and visualised by ethidium bromide staining.

\section{Linkage analysis}

Prior to embarking on a genomewide scan, we performed a linkage power calculation on pedigree PPKl using the SLINK software.42 Power calculations were performed under the assumption of an autosomal dominant trait with agedependent penetrance (age $0-10$ years, 0.01 ; age $11-15$ years, 0.30 ; age $16-25$ years, 0.80 ; age 26 years or older, 0.96 ), 500 replications, and a disease frequency of 0.001 .

Two-point and multipoint lod score analyses were performed for all markers genotyped in the genomewide scan. The linkage parameters used were the same as those described above for the linkage power calculations. Lod score values were calculated under two different scenarios in which unaffected individuals under 20 and 35 years of age were scored as unknown for linkage purposes. Two point analyses were carried out using the MLINK program of the FASTLINK suite of programs. ${ }^{43-45}$ Marker allele frequencies were estimated from the data obtained using observed and reconstructed genotypes of founders within the pedigrees. The alleles for all markers were re-coded using the RECODE program to avoid computational errors caused by observed allele frequencies of $0.0 .^{46}$ This re-coding program, which had no effect on any of the analyses, insured that alleles were numbered sequentially, and that every allelic frequency was non-zero.

Multipoint analyses were performed using the SimWalk program (version 2.6). ${ }^{47}$ This software employs a Markov chain Monte Carlo approach, which allows for both a large number of founders in a pedigree and multiple markers in the computation of lod scores. Markers were chosen for the multipoint analysis according to the following steps: (a) all markers that showed 0.0 recombination fractions with other markers according to the Marshfield genetic map ${ }^{41}$ were put into distinct groups; and (b) among markers within the distinct groups, those with the largest heterozygosity values were chosen for multipoint analysis. This procedure was followed because the method used in SimWalk has computational limitations for markers with 0.0 recombination distances (E Sobel, personal communication). The order and distance between the markers used in the multipoint analysis were deduced from the Marshfield genetic map. ${ }^{41}$ Haplotypes for markers on chromosome 15 were reconstructed using the SimWalk program, ${ }^{47}$ under the assumption of minimal recombination events.

\section{RESULTS}

\section{The punctate PPK phenotype}

The age of onset of the disease in families PPKI and PPK 2 (fig 1) ranged from 10 to 30 years old, although it was usually reported as later, as the lesions were mildly punctate and barely noticeable during the first years. Some of the lesions only became noticeable following water immersion. Keratotic lesions developed initially on the soles and within 2-3 years they progressed to involve the palms. Although the exact clinical involvement is sometimes difficult to document, as patients usually apply local treatments, there was a 
clear progression and worsening with time. The lesions became keratotic and increased in number during the patients' early 20 s and the involvement was very severe in older affected family members. The punctate component was more noticeable in the central part of the palms and soles, mainly on the palms, ranging from 30 to over 100 lesions (fig $2 \mathrm{~A}$ ). On the soles, the clinical picture was generally less specific, with large hyperkeratotic plaques in pressure areas (fig 2B), as seen with other keratodermas. ${ }^{48}$ There was also involvement of the lateral aspect and the tips of some fingers, with small wart-like hyperkeratotic lesions (fig 2C). There was no involvement of the dorsal aspects of the hands or legs, nor was there any involvement of the knees or elbows. Finally, there were no nail abnormalities.

Previous groups had reported association of punctate PPK with different types of malignancy. ${ }^{20}$ However, we did not observe an increased prevalence of malignancy in either of the first two families. The only case was that of an affected patient who died from breast cancer at the age of 94 years. The clinical findings in family PPK3 have been reported previously. ${ }^{37}$ Briefly, the proband (II:1) was an 83 year old male, presenting with multiple keratotic papules in his hands and feet, which progressed slowly. Histologically, the lesions displayed marked hyperkeratosis and hypergranulosis. As seen in pedigrees PPK1 and PPK2, he did not show any nail involvement. The proband died from pancreatic carcinoma and some of his siblings died from unknown types of cancer, according to their relatives.

\section{Genetic mapping of the locus for punctate PPK on chromosome 15}

Linkage power calculations on pedigree PPKl were performed to calculate the maximum theoretical lod score in the pedigree and the probability to achieve a lod score $>3$. We obtained lod score values of 5.73, 5.27, and 4.78 at recombination fraction of $0.00,0.05$, and 0.1 , respectively, and a probability of $89.4 \%$ for a lod score $>3$.

Given these highly positive values, we proceeded with the genomewide scan in pedigree PPKl. Two genetic loci yielded an initial two-point lod score $>1$, corresponding to three adjacent microsatellite markers on chromosome 15 , D15S1507 $(Z=2.92)$, D15S653 $(Z=2.72)$, and D15S643 $(Z=1.04)$, and one single marker on chromosome 21 , D21S1437 $(Z=1.77)$. Multipoint analysis with markers in the region of chromosome 21 suggested that this was a spurious positive lod score. This result, together with the fact that the three markers on chromosome 15 were consecutive, pointed to this region as the more likely location for the PPK gene in this family. Interestingly, none of the chromosomal regions containing genes previously involved in phenotypes of abnormal keratinisation achieved a promising positive lod score in the genomewide scan.

To confirm the identification of the locus for punctate PPK on chromosome 15, we genotyped 19 additional markers in the region in all available individuals. Lod score values were calculated under two different assumptions, scoring as unknown those unaffected individuals under the ages of 20 and 35 years. Maximum two-point lod scores of 4.70 (20 years of age) and 4.93 ( 35 years of age) were obtained for marker D15S988 at $\theta=0$, confirming the initial results from the genomewide scan (table 1). A maximum multipoint lod score of 5.22 supported the most likely location of the disease gene to be around marker D15S988.

To determine the most likely critical linkage interval, we reconstructed the haplotypes for markers in the region. Two key recombination events (fig 3A) in individuals III:7 (centromeric), and II:13 and III:1 (telomeric) placed the disease locus to a $9.98 \mathrm{cM}$ interval on 15q22-q24, flanked by markers D15S534 and D15S818. These observations were supported by additional recombination events observed in individuals II:2 and II:4.

In an attempt to determine whether punctate PPK is a genetically heterogeneous phenotype, pedigrees PPK2 and PPK3 were also genotyped for markers on chromosome 15. Haplotype analyses were consistent with cosegregation of the disease phenotype in these two pedigrees and the locus on chromosome 15 identified in pedigree PPKl (fig 3B, C).

\section{DISCUSSION}

According to one of the more accurate clinical classifications proposed so far, ${ }^{1}$ there are seven different sub-types of punctate PPK, including four acquired and three inherited forms. Based on the characteristic features for each of them, we have classified the families reported in this study as type I punctate PPK or Buschke-Fischer-Brauer disease, with the keratoses distributed over the entire palmoplantar surfaces

Table 1 Two-point lod scores for markers on 15q22q24 in pedigree PPK1

\begin{tabular}{|c|c|c|c|c|c|c|c|c|}
\hline \multirow[b]{2}{*}{ Marker } & \multirow{2}{*}{$\begin{array}{l}\text { Position } \\
\text { (cM) }\end{array}$} & \multicolumn{7}{|c|}{ Lod score ${ }^{*}$ at $\theta=$} \\
\hline & & 0 & 0.01 & 0.05 & 0.1 & 0.2 & 0.3 & 0.4 \\
\hline 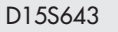 & & & & 0 & 6 & 39 & 94 & \\
\hline & & & & 1.30 & 1.51 & 1.37 & 0.93 & 3 \\
\hline & & 0.15 & 0.81 & 1.56 & 1.74 & 1.56 & 1.06 & 0.40 \\
\hline & & -0.74 & 0.25 & 1.04 & 1.27 & 1.19 & 0.80 & 0.27 \\
\hline & 61 & -1.22 & -0.23 & 0.56 & 0.80 & 0.74 & 0.44 & 0.11 \\
\hline & & & 2.28 & 2.40 & 2.30 & 1.85 & & 0.43 \\
\hline & & 2.0 & 2.04 & 1.86 & 1.63 & 1.15 & 0.65 & 0.20 \\
\hline & & 4.9 & 4.8 & 4.51 & 4.08 & 3. & & 0.86 \\
\hline & & 1. & 1.02 & 0.92 & 0.78 & 0.51 & & 0. \\
\hline D & 70 & 4.33 & 4.26 & 3.97 & 3.59 & 2.76 & 1.80 & 0.72 \\
\hline D1 & 71 & 2.36 & 2.38 & 2.35 & 2.17 & 1.64 & 0.97 & 0.32 \\
\hline D1 & 78.92 & 1.85 & 1.97 & 2.18 & 2.19 & 1.85 & 1.25 & 0.49 \\
\hline D15S655 & 82.84 & -0.49 & -0.34 & 0.02 & 0.21 & 0.29 & 0.21 & 0.09 \\
\hline
\end{tabular}

*Results shown for unaffected individuals under the age of 35 years scored as unknown for linkage purposes.
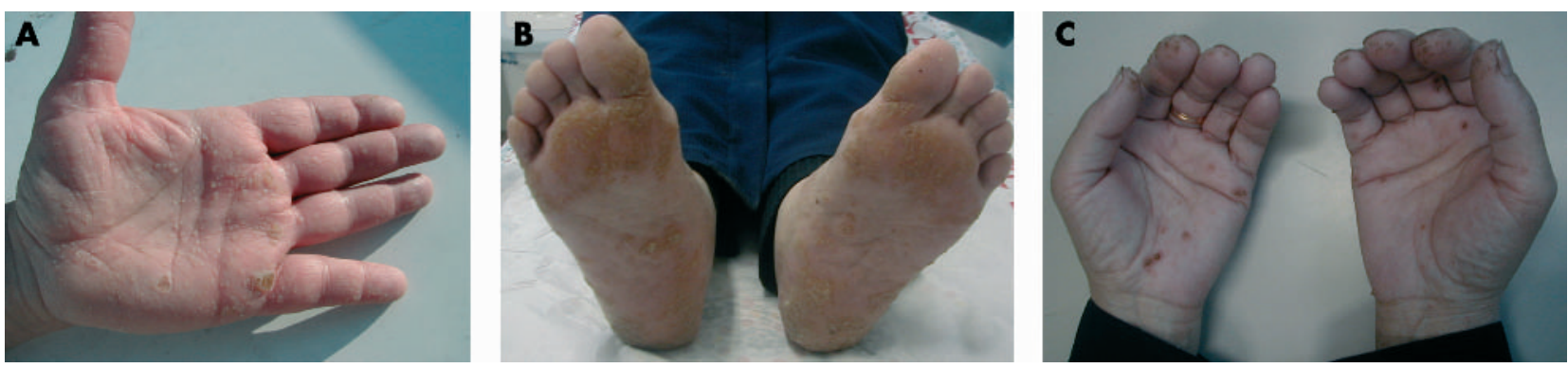

Figure 2 Clinical presentation of the PPK phenotype. (A) Palmar punctate lesions (PPK1); (B) plantar keratoderma involving pressure areas of heels, proximal soles, and the big toes (PPK2); and (C) involvement of the lateral aspects and tips of fingers (PPK2). 

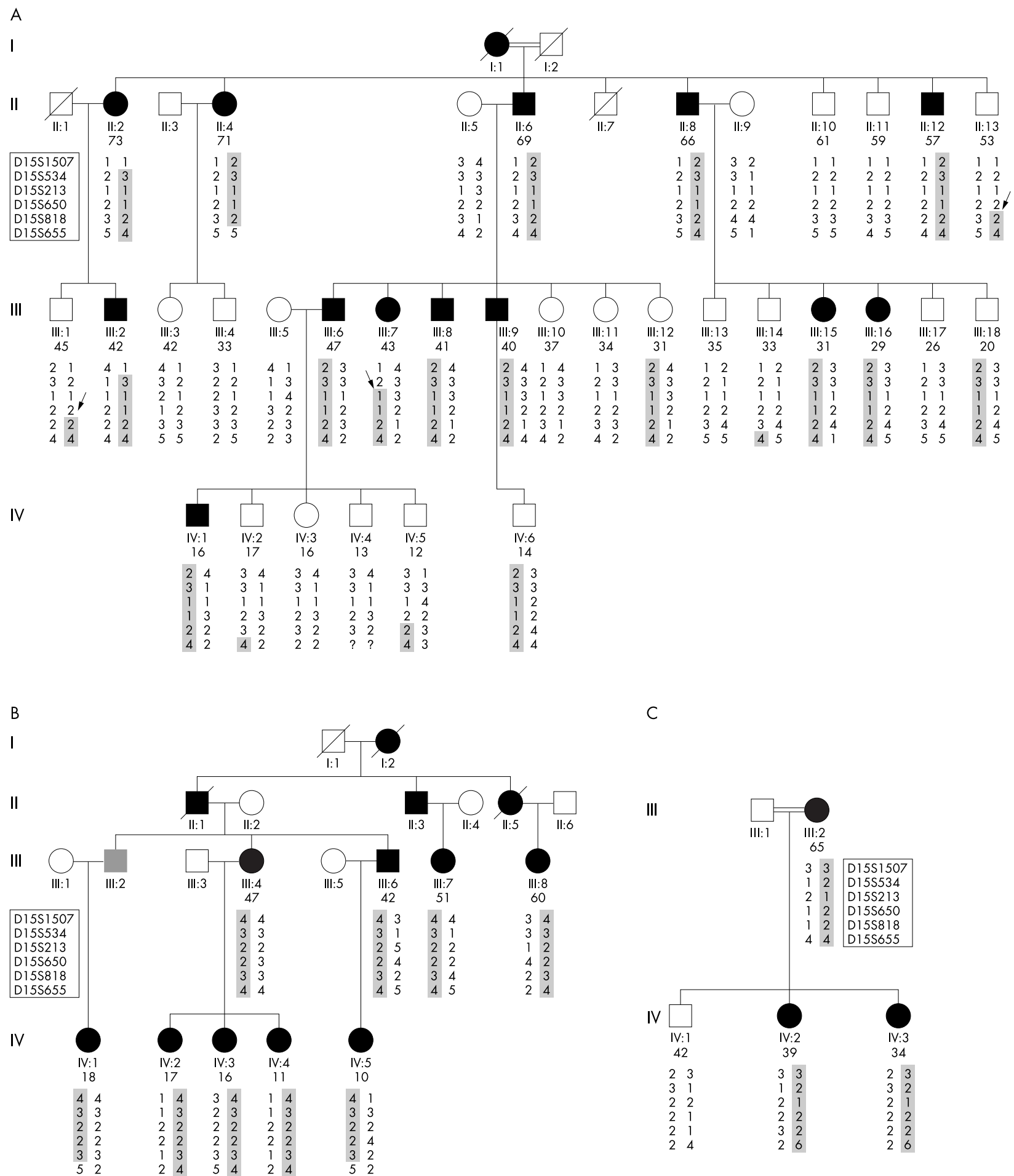

C

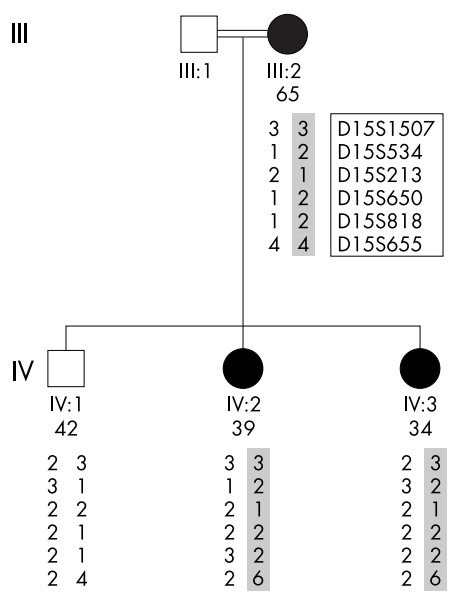

Figure 3 Simplified pedigrees for families PPK1, PPK2 and PPK3 showing the haplotypes for markers on chromosome 15q22-q24. The age at the time of the study is shown and markers analysed are indicated in each panel. The disease associated-chromosome is shaded. Key recombination events (II: 13, III: 1 and III:7 in PPK1) are indicated by arrows. A question mark indicates that the genotype was not available.

and coalescing into a more diffuse pattern over the pressure points of the sole.

In the present study, we have identified the locus for type I punctate PPK on chromosome 15q22-q24. The analysis of the disease-associated haplotype in pedigree PPKl revealed the presence of three asymptomatic carriers, III:12, III:18, and IV:6 (fig 3A), aged 31, 20, and 14 years at the time of the study, respectively. The most likely explanation for this is the characteristic age dependent penetrance in this form of PPK, especially for III:18 and IV:6. In fact, previous reports on families with inherited punctate PPK gave an estimated age of onset between 10 and 33 years old. ${ }^{1}{ }^{10} 35$ Moreover, IV:6 was suspected to present lesions on his palms after clinical evaluation, and previous to any genetic study. Two other unaffected individuals, II:13 and III: 1, were shown to carry a partial disease-associated haplotype, representing recombi- 
nation events (fig 3A). Although their ages, 53 and 45 years old, respectively, were above the age of onset in the family (10-30 years of age), the possibility of reduced penetrance cannot be ruled out, and thus, these recombination events must be considered with caution. The analysis of markers within the identified critical linkage interval in pedigrees PPK2 and PPK3 also showed co-segregation with the disease phenotype (fig 3B, C), suggesting genetic homogeneity among the three punctate PPK families studied here. As the number of available samples from these two pedigrees was small, the analysis both of additional family members and of new families with the same PPK phenotype will be necessary to evaluate the possibility of locus heterogeneity in punctate PPK.

According to the physical maps at NCBI, UCSC (build \#33), and deCODE Genetics, ${ }^{49}$ the critical linkage interval identified here corresponds to a region of $7.5 \mathrm{Mb}$ (fig 4). Among both known and predicted genes, we identified one promising candidate, locus LOC123396, highly homologous to keratin 8. Considering the role of keratins in different forms of PPK, ${ }^{16-18}{ }^{20-22}$ this novel gene appeared to be an excellent candidate for the punctate PPK phenotype studied here. The predicted gene encompasses a genomic region of $1398 \mathrm{bp}$, with three exons, supported by the alignment with eight EST clones. The encoded predicted protein would be 403 amino acids long, with high homology to different keratin proteins, such as keratin 8 (74\% identity at the amino acid level); keratin $1(51 \%)$, mutated in non-epidermolytic PPK; ${ }^{16}$ keratins $6 \mathrm{a}$ and $6 \mathrm{~b}(59 \%)$, mutated in pachyonychia congenita, a nail abnormality that presents with PPK; ${ }^{17}{ }^{18}$ and keratin 5 (59\%), mutated in epidermolysis bullosa simplex..$^{50}$ Sequencing of the genomic region containing locus LOC123396 in the three PPK pedigrees studied here, however, did not reveal any pathogenetic mutations. We detected two missense substitutions, A358T and R392C (accession \#XP 063639), that were also present in control individuals. In addition, pairwise sequence alignment between LOC123396 and KRT8 suggested that LOC123396 could represent a processed pseudogene. In this regard, Hesse et al ${ }^{51}$ have recently performed a thorough search for novel intermediate filament genes in the draft sequence of the human genome. As a result, they have described a "surprisingly high number of pseudogenes" related to KRT8. ${ }^{51}$

It is worth mentioning the presence of two additional positional candidate genes within the linkage interval, integrin alpha 11 (ITGA11) and lysyl oxidase-like 1 (LOXL1) genes. Integrins constitute a family of proteins that mediate the interaction between different cell types and the extracellular matrix. ITGAl1, in particular, has been hypothesised to play a role in areas of highly organised interstitial collagen networks, ${ }^{52}$ such as cartilage, intervertebral disc, and corneal organogenesis. Although there is no information on the expression of ITGAll in skin, the proven role of adhesion molecules in PPK, such as desmosomal components, ${ }^{15}$ makes ITGAll a candidate gene for the disease in our families. LOXL1, on the other hand, is a new member of the lysyl oxidase protein family of cross-linking enzymes for extracellular matrix proteins such as collagen and elastin. Human LOXL1 mRNA has been identified in a wide variety of tissues, but no information is available regarding its expression in
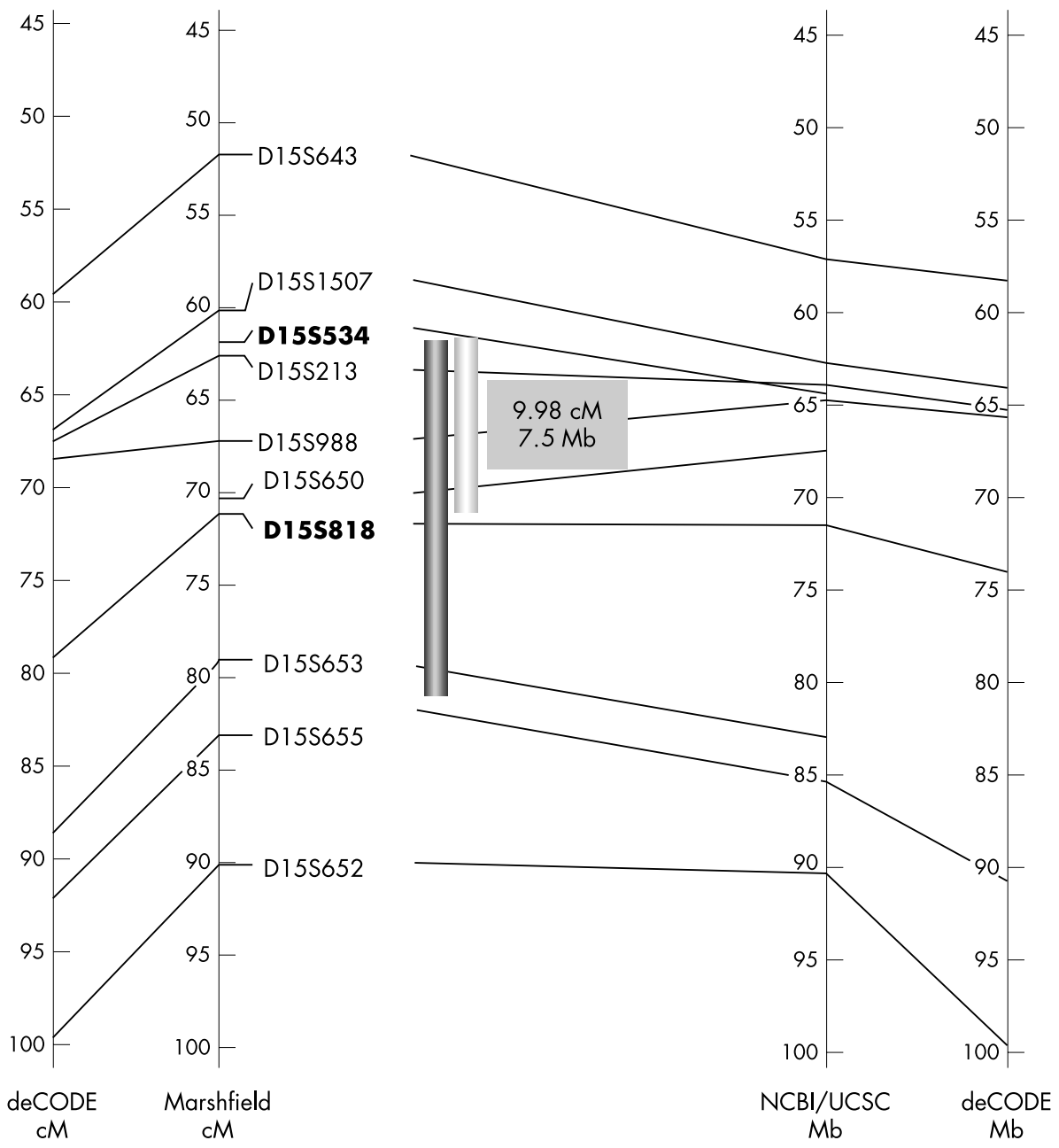

Figure 4 Schematic representation of chromosome 15 showing the position of markers used in this study and the linkage intervals identified. Markers defining the locus for punctate PPK are indicated in bold. The critical linkage interval defined by recombination events in affected individuals only (dark bar), and affected and unaffected individuals over the age of 40 years (light bar) are indicated. Genetic distances (cM) are based on the maps at Marshfield ${ }^{41}$ and deCODE Genetics; ${ }^{49}$ physical positions (Mb) have been obtained from NCBI, UCSC (build \#33), and the integrated map at deCODE genetics. ${ }^{49}$ 


\section{Electronic database information}

- Center for Medical Genetics, Marshfield Medical Research Foundation, hitp://research.marshfieldclinic. org/genetics/.

- Cooperative Human Linkage Center (CHLC), http:// lpg.nci.nih.gov/CHLC.

- The Genome Database (GDB), http://www.gdb.org.

- UCSC Human Genome Working Draft ("Golden Path"), http://genome.ucsc.edu/index.html.

- National Center for Biotechnology Information (NCBI), http://www.ncbi.nlm.nih.gov.

- Online Mendelian Inheritance in Man (OMIM), http:// www.ncbi.nih.nlm.gov/Omim.

skin. Mouse Loxll protein, on the other hand, has been detected in mouse epidermis and hair follicle, as well as heart, liver, and kidney. ${ }^{53}$ Finally, the syntenic region on mouse chromosome 9 does not harbour any candidate gene for the punctate PPK phenotype.

In summary, we have identified a locus for punctate PPK, on chromosome 15q22-q24, which indicates the identification of a novel gene involved in skin integrity. The study of multigenerational pedigrees with inherited diseases, such as those reported here, provides us with an excellent opportunity for the identification of new genes and pathways, and for the study of their function in both normal and diseased individuals. When these diseases are associated with a more systemic clinical picture, the identification of disease genes may give new insights into the aetiology of other pathologies, such as the cardiomyopathy associated with PPK in Naxos disease. Moreover, as is the case for some skin disorders, such as Netherton syndrome and atopic dermatitis, ${ }^{54} 55$ the knowledge gathered from rare Mendelian disorders such as PPK could produce important clues for more common complex traits characterised by abnormal keratinisation, such as

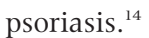

\section{ACKNOWLEDGEMENTS}

The authors wish to thank all the family members for their invaluable contribution to this study, $\mathrm{H}$ Lam and S Tornovsky for expert technical assistance and T Waran Lalin for her help in the final steps of this work. This study was supported by the Skin Disease Research Center, Department of Dermatology, Columbia University (P30 AR44535), research grants from the National Institutes of Health R01-AR44924 (to A Martinez-Mir), K01-HG00055 (to D Gordon), and MH59492 (to J Ott, as mentor of D Londono), and by a grant from the Joint Research Fund of the Hebrew University and Hadassah, Jerusalem, Israel (to A Zlotogorski).

\section{Authors' affiliations}

A Martinez-Mir, A M Christiano, Department of Dermatology, Columbia University, New York, NY, USA

A M Christiano, Department of Genetics and Development, Columbia University, New York, NY, USA

A Zlotogorski, L Horev, O Alayan, Department of Dermatology, Hadassah-Hebrew University Medical Center, Jerusalem, Israel D Londono, D Gordon, Laboratory of Statistical Genetics, Rockefeller University, New York, NY, USA

D Londono, Department of Epidemiology and Biostatistics, Rammelkamp Center for Education and Research, Case Western Reserve University, Cleveland, $\mathrm{OH}$, USA

A Grunn, J Liu, T C Gilliam, Columbia Genome Center, Columbia University, New York, NY, USA

J Liu, Population Genetics, Genome Institute of Singapore, National University of Singapore, Singapore

E Uribe, I M Ruiz, N O Davalos, Hospital General de Occidente
Zapopán, Jalisco, México

J C Salas-Alanis, Departamento de Dermatología, Servicio Médico Universidad Autónoma de Nuevo León, Monterrey NL, México

\section{REFERENCES}

1 Stevens HP, Kelsell DP, Bryant SP, Bishop DT, Spurr NK, Weissenbach J, Marger D, Marger RS, Leigh IM. Linkage of an American pedigree with palmoplantar keratoderma and malignancy (palmoplantar ectodermal dysplasia type III) to 17q24. Literature survey and proposed updated classification of the keratodermas. Arch Dermatol 1996;132:640-51.

2 Stevens HP, Kelsell DP, Leigh IM, Ostlere LS, MacDermot KD, Rustin MH. Punctate palmoplantar keratoderma and malignancy in a four-generation family. Br J Dermatol 1996; 134:720-6

3 Coonar AS, Protonotarios N, Tsatsopoulou A, Needham EW, Houlston RS, Cliff S, Otter MI, Murday VA, Mattu RK, McKenna WJ. Gene for arrhythmogenic right ventricular cardiomyopathy with diffuse nonepidermolytic palmoplantar keratoderma and woolly hair (Naxos disease) maps to 17q21. Circulation 1998;97:2049-58.

4 Norgett EE, Hatsell SJ, Carvajal-Huerta L, Cabezas JC, Common J, Purkis PE, Whittock N, Leigh IM, Stevens HP, Kelsell DP. Recessive mutation in desmoplakin disrupts desmoplakin-intermediate filament interactions and causes dilated cardiomyopathy, woolly hair and keratoderma. Hum Mol Genet 2000;9:2761-6.

5 Diabali K, Martinez-Mir A, Horev L, Christiano AM, Zlotogorski A. Evidence for extensive locus heterogeneity in Naxos disease. $J$ Invest Dermatol 2002; 118:557-60.

6 Sevior KB, Hatamochi A, Stewart IA, Bykhovskaya Y, Allen-Powell DR, FischelGhodsian N, Maw MA. Mitochondrial A7445G mutation in two pedigrees with palmoplantar keratoderma and deafness. Am J Med Genet 1998:75:179-85.

7 Heathcote K, Syrris P, Carter ND, Patton MA. A connexin 26 mutation causes a syndrome of sensorineural hearing loss and palmoplantar hyperkeratosis (MIM 148350). J Med Genet 2000;37:50-1.

8 Howel-Evans W, McConnell RB, Clarke CA, Sheppard PM. Carcinoma of the oesophagus with keratosis palmaris et plantaris (tylosis): a study of two families. Quart J Med 1958;27:413-29.

9 Huriez C, Deminatti M, Agache P, Mennecier M. A gene dysplasia not previously known: frequently degenerative sclero-atrophying and keratodermic genodermatosis of the extremities. Sem Hop 1968:44:481-8.

10 Bennion SD, Patterson JW. Keratosis punctata palmaris et plantaris and adenocarcinoma of the colon. A possible familial association of punctate keratoderma and gastrointestinal malignancy. J Am Acad Dermatol 1984; 10:587-91.

11 Blanchet-Bardon C, Nazzaro V, Chevrant-Breton J, Espie M, Kerbrat P, Le Marec B. Hereditary epidermolytic palmoplantar keratoderma associated with breast and ovarian cancer in a large kindred. Br J Dermatol 1987; 117:363-70.

12 Torchard D, Blanchet-Bardon C, Serova O, Langbein L, Narod S, Janin N, Goguel AF, Bernheim A, Franke WW, Lenoir GM, Feunteun J. Epidermolytic palmoplantar keratoderma cosegregates with a keratin 9 mutation in a pedigree with breast and ovarian cancer. Nat Genet 1994;6:106-10.

13 Friedman LS, Szabo Cl, Ostermeyer EA, Dowd P, Butler L, Park T, Lee MK, Goode EL, Rowell SE, King MC. Novel inherited mutations and variable expressivity of BRCA1 alleles, including the founder mutation 185delAG in Ashkenazi Jewish families. Am J Hum Genet 1995;57:1284-97.

14 Kelsell DP, Stevens HP. The palmoplantar keratodermas: much more than palms and soles. Mol Med Today 1999:5:107-13.

15 Kimyai-Asadi A, Kotcher LB, Jih MH. The molecular basis of hereditary palmoplantar keratodermas. J Am Acad Dermatol 2002;47:327-43.

16 Kimonis V, DiGiovanna JJ, Yang JM, Doyle SZ, Bale SJ, Compton JG. A mutation in the $\mathrm{Vl}$ end domain of keratin 1 in non-epidermolytic palmarplantar keratoderma. J Invest Dermatol 1994;103:764-9.

17 Bowden PE, Haley JL, Kansky A, Rothnagel JA, Jones DO, Turner RJ. Mutation of a type II keratin gene (K6a) in pachyonychia congenita. Nat Genet $1995 ; 10: 363-5$.

18 Smith FJ, Jonkman MF, van Goor H, Coleman CM, Covello SP, Uitto J, McLean WH. A mutation in human keratin K6b produces a phenocopy of the $\mathrm{K} 17$ disorder pachyonychia congenita type 2. Hum Mol Genet 1998;7: 1143-8.

19 Reis A, Kuster W, Eckardt R, Sperling K. Mapping of a gene for epidermolytic palmoplantar keratoderma to the region of the acidic keratin gene cluster at 17q12-q21. Hum Genet 1992;90:113-16.

20 Reis A, Hennies HC, Langbein L, Digweed M, Mischke D, Drechsler M, Schrock E, Royer-Pokora B, Franke WW, Sperling K, Kuster W. Keratin 9 gene mutations in epidermolytic palmoplantar keratoderma (EPPK). Nat Genet 1994:6:174-9.

21 McLean WH, Rugg EL, Lunny DP, Morley SM, Lane EB, Swensson O, DoppingHepenstal PJ, Griffiths WA, Eady RA, Higgins C, Navsaria HA, Leigh IM, Strachan T, Kunkeler L, Munro CS. Keratin 16 and keratin 17 mutations cause pachyonychia congenita. Nat Genet 1995:9:273-8.

22 Munro CS, Carter S, Bryce S, Hall M, Rees JL, Kunkeler L, Stephenson A, Strachan T. A gene for pachyonychia congenita is closely linked to the keratin gene cluster on 17q12-q21. J Med Genet 1994;31:675-8.

23 Hennies HC, Kuster W, Mischke D, Reis A. Localization of a locus for the striated form of palmoplantar keratoderma to chromosome $18 \mathrm{q}$ near the desmosomal cadherin gene cluster. Hum Mol Genet 1995;4:1015-20.

24 Armstrong DK, McKenna KE, Purkis PE, Green KJ, Eady RA, Leigh IM Hughes AE. Haploinsufficiency of desmoplakin causes a striate subtype of palmoplantar keratoderma. Hum Mol Genet 1999;8:143-8. 
25 Whittock NV, Wan H, Morley SM, Garzon MC, Kristal L, Hyde P, McLean WH, Pulkkinen L, Uitto J, Christiano AM, Eady RA, McGrath JA. Compound heterozygosity for nonsense and missense mutations in desmoplakin underlies skin fragility/woolly hair syndrome. J Invest Dermatol 2002:118:232-8.

26 McKoy G, Protonotarios N, Crosby A, Tsatsopoulou A, Anastasakis A, Coonar A, Norman M, Baboonian C, Jeffery S, McKenna WJ. Identification of a deletion in plakoglobin in arrhythmogenic right ventricular cardiomyopathy with palmoplantar keratoderma and woolly hair (Naxos disease). Lancet 2000:355:2119-24.

27 Maestrini E, Korge BP, Ocana-Sierra J, Calzolari E, Cambiaghi S, Scudder PM, Hovnanian A, Monaco AP, Munro CS. A missense mutation in connexin26, D66H, causes mutilating keratoderma with sensorineural deafness (Vohwinkel's syndrome) in three unrelated families. Hum Mol Genet 1999:8:1237-43.

28 Kibar Z, Der Kaloustian VM, Brais B, Hani V, Fraser FC, Rouleau GA. The gene responsible for Clouston hidrotic ectodermal dysplasia maps to the pericentromeric region of chromosome 13q. Hum Mol Genet 1996;5:543-7.

29 Lamartine J, Munhoz Essenfelder G, Kibar Z, Lanneluc I, Callouet E, Laoudi D Lemaitre G, Hand C, Hayflick SJ, Zonana J, Antonarakis S, Radhakrishna U, Kelsell DP, Christianson AL, Pitaval A, Der Kaloustian V, Fraser C, BlanchetBardon C, Rouleau GA, Waksman G. Mutations in GJB6 cause hidrotic ectodermal dysplasia. Nat Genet 2000;26:142-4.

30 Richard G, Smith LE, Bailey RA, Itin P, Hohl D, Epstein EH Jr, DiGiovanna JJ Compton JG, Bale SJ. Mutations in the human connexin gene GJB3 cause erythrokeratodermia variabilis. Nat Genet 1998;20:366-9.

31 Maestrini E, Monaco AP, McGrath JA, Ishida-Yamamoto A, Camisa C, Hovnanian A, Weeks DE, Lathrop M, Uitto J, Christiano AM. A molecular defect in loricrin, the major component of the cornified cell envelope, underlies Vohwinkel's syndrome. Nat Genet 1996;13:70-7.

32 Toomes C, James J, Wood AJ, Wu CL, McCormick D, Lench N, Hewitt C, Moynihan L, Roberts E, Woods CG, Markham A, Wong M, Widmer R, Ghaffar KA, Pemberton M, Hussein IR, Temtamy SA, Davies R, Read AP, Sloan P, Dixon MJ, Thakker NS. Loss-of-function mutations in the cathepsin C gene result in periodontal disease and palmoplantar keratosis. Nat Genet 1999;23:421-4

33 Fischer J, Bouadjar B, Heilig R, Huber M Lefevre C, Jobard F, Macari F, Bakija-Konsuo A, Ait-Belkacem F, Weissenbach J, Lathrop M, Hohl D, Prud'homme JF. Mutations in the gene encoding SLURP-1 in Mal de Meleda. Hum Mol Genet 2001;10:875-80.

34 Stanimirovic A, Kansky A, Basta-Juzbasic A, Skerlev M, Beck T. Hereditary palmoplantar keratoderma, type papulosa, in Croatia. J Am Acad Dermatol 1993;29:435-7.

35 Emmert S, Kuster W, Hennies HC, Zutt M, Haenssle H, Kretschmer L, Neumann C. 47 patients in 14 families with the rare genodermatosis keratosis punctata palmoplantaris Buschke-Fischer-Brauer. Eur J Dermatol 2003:13:16-20.

36 Kelsell DP, Stevens HP, Ratnavel R, Bryant SP, Bishop DT, Leigh IM, Spurr NK Genetic linkage studies in non-epidermolytic palmoplantar keratoderma: evidence for heterogeneity. Hum Mol Genet 1995;4:1021-5.

37 Davalos N, Ruiz M, Garcia-Vargas A, Davalos IP, Garcia-Cruz D, Figuera LE. Punctata keratoderma and gastrointestinal malignancy in a Mexican family. Am J Hum Genet 2001;69:S287

38 Aita VM, Liu J, Knowles JA, Terwilliger JD, Baltazar R, Grunn A, Loth JE, Kanyas K, Lerer B, Endicott J, Wang Z, Penchaszadeh G, Gilliam TC, Baron M.
A comprehensive linkage analysis of chromosome 21 q22 supports prior evidence for a putative bipolar affective disorder locus. Am J Hum Genet 1999;64:210-17.

39 Liu J, Nyholt DR, Magnussen P, Parano E, Pavone P, Geschwind D, Lord C, Iversen $\mathrm{P}$, Hoh J, OH J, Gilliam TC. A genomewide screen for autism susceptibility loci. Am J Hum Genet 2001;69:327-40.

40 Liu J, Juo SH, Holopainen P, Terwilliger J, Tong X, Grunn A, Brito M, Green P, Mustalahti K, Maki M, Gilliam TC, Partanen J. Genomewide linkage analysis of celiac disease in Finnish families. Am J Hum Genet 2002;70:51-9.

41 Broman KW, Murray JC, Sheffield VC, White RL, Weber JL. Comprehensive human genetic maps: individual and sex-specific variation in recombination. Am J Hum Genet 1998;63:861-9.

$42 \mathrm{OHJ}$. Computer-simulation methods in human linkage analysis. Proc Natl Acad Sci USA 1989;86:4175-8.

43 Lathrop GM, Lalouel JM, Julier C, Ott J. Strategies for multilocus linkage analysis in humans. Proc Natl Acad Sci USA 1984;81:3443-6.

44 Cottingham RW, Jr, Idury RM, Schaffer AA. Faster sequential genetic linkage computations. Am J Hum Genet 1993;53:252-63.

45 Schaffer AA, Gupta SK, Shriram K, Cottingham RW Jr. Avoiding recomputation in linkage analysis. Hum Hered 1994:44:225-37.

46 Weeks DE. RECODE - a program for recoding base-pair sized alleles into integer-numbered alleles. ftp://watson.hgen.edu/pub/recode.tar.Z, 2000.

47 Sobel E, Lange K. Descent graphs in pedigree analysis: applications to haplotyping, location scores, and marker-sharing statistics. Am J Hum Genet 1996:58:1323-37.

48 Kljuic A, Gilead L, Martinez-Mir A, Frank J, Christiano AM, Zlotogorski A. A nonsense mutation in the desmoglein 1 gene underlies striate keratoderma. Exp Dermatol 2003;12:523-7.

49 Kong A Gudbjartsson DF, Sainz J, Jonsdottir GM, Gudjonsson SA Richardsson B, Sigurdardottir S, Barnard J, Hallbeck B, Masson G, Shlien A, Palsson ST, Frigge ML, Thorgeirsson TE, Gulcher JR, Stefansson K. A highresolution recombination map of the human genome. Nat Genet 2002;31:241-7.

50 Lane EB, Rugg EL, Navsaria H, Leigh IM, Heagerty AH, Ishida-Yamamoto A, Eady RA. A mutation in the conserved helix termination peptide of keratin 5 in hereditary skin blistering. Nature 1992;356:244-6.

51 Hesse M, Magin TM, Weber K. Genes for intermediate filament proteins and the draft sequence of the human genome: novel keratin genes and a surprisingly high number of pseudogenes related to keratin genes 8 and 18 . J Cell Sci 2001;114:2569-75.

52 Tiger CF, Fougerousse F, Grundstrom G, Velling T, Gullberg D. Alpha 11 betal integrin is a receptor for interstitial collagens involved in cell migration and collagen reorganization on mesenchymal nonmuscle cells. Dev Biol 2001;237:116-29.

53 Molnar J, Fong KS, He QP, Hayashi K, Kim Y, Fong SF, Fogelgren B Szauter KM, Mink M, Csiszar K. Structural and functional diversity of lysyl oxidase and the LOX-like proteins. Biochim Biophys Acta 2003; 1647:220-4.

54 Walley AJ, Chavanas S, Moffatt MF, Esnouf RM, Ubhi B, Lawrence R, Wong K, Abecasis GR, Jones EY, Harper JI, Hovnanian A, Cookson WO. Gene polymorphism in Netherton and common atopic disease. Nat Genet 2001;29:175-8.

55 Norgett EE, Kelsell DP. SPINK5: both rare and common skin disease. Trends Mol Med 2002;8:7. 